\title{
Article \\ Design and Development of Innovative Steam Injection for High-Temperature Short-Time Liquid Foods
}

\author{
Wilasinee Sangsom and Chouw Inprasit *
}

check for updates

Citation: Sangsom, W.; Inprasit, C. Design and Development of Innovative Steam Injection for High-Temperature Short-Time Liquid Foods. Processes 2022, 10, 161 . https://doi.org/10.3390/pr10010161

Academic Editor: Anet Režek Režek Jambrak

Received: 18 December 2021

Accepted: 8 January 2022

Published: 14 January 2022

Publisher's Note: MDPI stays neutral with regard to jurisdictional claims in published maps and institutional affiliations.

Copyright: (C) 2022 by the authors. Licensee MDPI, Basel, Switzerland. This article is an open access article distributed under the terms and conditions of the Creative Commons Attribution (CC BY) license (https:// creativecommons.org/licenses/by/ $4.0 /)$.
Department of Food Engineering, Faculty of Engineering at Kamphaeng Saen, Kasetsart University, Kamphaeng Saen Campus, Nakhon Pathom 73140, Thailand; wilasinee.sang@ku.th

* Correspondence: fengchi@ku.ac.th; Tel.: +66-8-1803-5716

\begin{abstract}
Jet impingement has been effective in reducing the process time and improvement of product quality in various industrial applications, such as textile and paper drying, electronic cooling, glass quenching and food processing. The current work applied innovative steam injection to liquid food continuous sterilization. The multiple impingement jets of steam and product came together in the impingement tank. The effects were investigated on the Reynolds number, steam temperature and jet-to-target spacing $(\mathrm{H} / \mathrm{d})$, sterilization temperature and heat transfer efficiency in water and pineapple juice tests. The Reynolds number was based on the nozzle configuration and liquid flow rate. The study investigated product injection plates formed using two, three or four circular holes (diameter $2 \mathrm{~mm}$ ), steam injection plates with six, nine or twenty circular holes (diameter $1 \mathrm{~mm}$ ), steam temperatures of 120,125 or $130^{\circ} \mathrm{C}$ and $\mathrm{H} / \mathrm{d}$ values of $1,3,5$ or 7 . The different options were tested with water to determine the optimal conditions, and then tested with pineapple juice. The results showed that the optimal conditions from water testing that provided the highest heat transfer efficiency occurred with two jet nozzles, six steam injection plates, a steam temperature of $120{ }^{\circ} \mathrm{C}$ and an $\mathrm{H} / \mathrm{d}$ value of 1 .
\end{abstract}

Keywords: steam injection; jet impingement; sterilization; heat transfer; direct heating

\section{Introduction}

In the continuous sterilization of liquid foods, thermal damage to the product is minimized by using the highest possible temperature for the shortest time needed to achieve the required sterilizing effect. The exposure time to the sterilization temperature depends on the length of pipe in the holding section [1-3]. Heating is principally achieved either by using indirect transfer of heat from a heating medium to the product through a stainless steel wall or by direct mixing of the product with culinary steam.

In an indirect system, the types of heat exchanger available can be subdivided according to the form taken by the heat transfer surface as plate, tubular, or scraped-surface heat exchangers. The most suitable type depends on the properties of the liquid food [3]. The heat exchanger can be designed for heat recovery, where plate heat exchanger efficiency can be up to $90 \%$, while using a tubular heat exchanger, the maximum that can usually be achieved is $70-75 \%$. However, heat transfer efficiency is significantly reduced by fouling on the hot surface [4]. This results in increased costs of energy to overcome the thermal resistance of the fouling layer, for cleaning in terms of the amount of chemical used for wastewater disposal, and in reduced processing times due to cleaning downtime [3].

In a direct heating method, when the steam comes into contact with the product it condenses and releases latent heat causing the product to heat up very quickly with less fouling problems compared to an indirect method [5]. The process of injecting steam into a product is called injection, while the process in which a product is injected into steam is called infusion [3]. Direct contact condensation of the steam jet in subcooled water has been widely used in various processes [6]. 
Another interesting direct heating technology is the use of an impingement steam jet to increase the heat transfer efficiency. Jet impingement on a surface generates a large convection coefficient and creates a high heat transfer rate [7]. Therefore, the jet impingement technique is extensively used in various industrial applications such as textile and paper drying, electronic cooling, glass quenching and cooling of turbine blades. It is also used in industrial food processing to reduce the process time and improve product quality through drying, baking, cooling and freezing [8]. Impingement jets are not restricted to use between a fluid and a surface or solid but can also be applied between liquids. Dispersed liquidliquid flows have many applications in the process, food and pharmaceutical industries, as well as in wastewater treatment [9].

Often, multiple jets are used with the aim of evenly distributing heat transfer along the surface. The flow structure of multiple impingement jets has the same three flow regions (free jet, stagnation, wall jet) as a single impingement jet. However, the flows are further complicated by interactions between these regions. There is possible jet interference before impingement and jet fountains (upwash flow) between two adjacent jets after impingement. A secondary stagnation region with an upwash flow may appear in the space between the jets, which affects heat transfer on the target surface $[10,11]$.

The efficiency of an impingement system is affected by many parameters, including the Reynolds Number, and the design of the injection and nozzle configurations (type, size and shape of nozzles) [12,13]. The current study investigates these parameters of an impingement jet.

Orifice jets are well known for their interesting characteristics, such as the vena contracta effect, which is the contraction of fluid when it is forced through a sharp-edged orifice that produces high mixing performance and good heat transfer characteristics. The orifice jet can significantly enhance the local Nusselt number. For example, it increases by $17 \%$ and $33 \%$ at the stagnation point as compared to pipe and the quadrant jets, respectively $[7,14]$.

Under turbulent flow conditions, the increase in heat transfer rate is more substantial than under laminar flow conditions. Turbulent flow has a Reynolds number greater than 4000, and typical gas jet installations for heat transfer span a Reynolds number range from 4000 to $80,000[13,15,16]$. Ekkad et al. [17] studied the effect of jet Reynolds number $(5000$, $10,000,150,00)$, the jet-to-jet spacing or pitch (t/d), and the jet-to-target distance $(\mathrm{H} / \mathrm{d})$ on heat transfer. They found the Nusselt numbers increase significantly as Reynolds number increases. The mixing effect is stronger as Reynolds number increases.

Heat transfer increases with an increase in the Reynolds number, with Nusselt number being proportional to $\operatorname{Re}^{0.5}$ to 0.8 . For a constant Reynolds Number, decreasing the jet diameter increases the average heat transfer coefficient due to the higher jet velocities created by smaller nozzles [18]. Typically, for small-scale applications, jet arrays have a diameter of $0.2-2 \mathrm{~mm}$, while for larger-scale industrial applications, jet diameters are in the range 5-30 $\mathrm{mm}$ [13]. Mistry et al. [19] studied sterilization using an innovative steam injection (ISI) heater with a narrow pipe (1-3 $\mathrm{mm}$ in diameter) as the nozzle. Inlet steam pressure is the essential factor influencing the shape and length of the steam plume. When the steam pressure at the nozzle inlet increases the length of steam plume increases.

The heat transfer area in the gas-liquid two-phase region increases to complete the condensation of steam [20].

For a multiple impingement jet, the parameters that need to be considered in the correlations include the jet-to-jet spacing or pitch $(t / d)$, the jet-to-target distance $(\mathrm{H} / \mathrm{d})$ and the arrangement of the nozzles in the array. Interference effects are enhanced when the jets are closely spaced and when the jet-to-target distance is relatively large. Furthermore, collisions increase when the jets are closely spaced, the nozzle-to-plate distance is small and the jet velocity is high [6,9]. Specht [10] studied the influence of pitch on heat transfer in multiple jet types. At $t / d=6$, there is always a pronounced maximum average Nusselt number for arrays of single nozzles. For the hole channel type, up to a pitch of about 6 , the average Nusselt number remains effectively constant, but after this point it decreases. For perforated plates, the maximum heat transfer occurs at $t / d$ values in the range $3-5$, 
depending on the distance between the jet and the target. Yamane et al. [21] investigated the effect of injection parameters on circular jet array impingement heat transfer and reported that the area-averaged Nusselt number was high for $t / d=4$ compared to $t / d=6$ or 8. Geers [7] found the maximum area-averaged heat transfer occurred at $t / d=5.5$ for a hexagonal array of round nozzles, regardless of the value of $\mathrm{H} / \mathrm{d}$. At $\mathrm{t} / \mathrm{d}$ values greater than 5.5, the impinged area per jet is large, which causes low area-averaged Nusselt numbers, while at a $\mathrm{t} / \mathrm{d}$ value smaller than 5.5 , there is significant interference between the jets, causing a decrease in the jet velocity.

Multiple jet arrays with low values of $\mathrm{H} / \mathrm{d}$ produce high area-averaged heat transfer coefficients due to the smaller distance in which the interactions occur [7]. Specht [10] found that the heat transfer was highest for $\mathrm{H} / \mathrm{d}$ in the range $1<\mathrm{H} / \mathrm{d}<5$ but then decreased continuously with increasing distance. However, Lytle and Webb [22] reported increasing heat transfer with decreasing $\mathrm{H} / \mathrm{d}$ from 6 to 0.1 .

Usually, steam injection and steam infusion are used in the direct heating method, but due to the high efficiency of heat and mass transfer of the impingement steam jet, the current research applied this technique for high-temperature short-time sterilization to improve product quality. The purpose of the current study was to investigate heat transfer characteristics using multiple jet impingement in a continuous sterilizer application and to investigate the thermal efficiency of an impingement jet sterilizer based on various parameters including Reynolds number (4000-72,000) and jet-to-target spacing (H/d,1-7), with jet-to-jet spacing $(\mathrm{t} / \mathrm{d})$ constant at 5.5 and steam temperatures of 120,125 and $130{ }^{\circ} \mathrm{C}$. Optimal conditions were applied for the sterilization of pineapple juice. Pineapple juice is suited to an instant sterilization method, where the temperature is $91-95^{\circ} \mathrm{C}$ for $15-30 \mathrm{~s}$ [23].

\section{Materials and Methods}

\subsection{Design of Continuous Thermal Sterilizer Using Impingement Steam Jet}

The main equipment in the pilot-scale sterilizer consisted of a product buffer tank (5.6 L), a centrifugal product pump (Iwaya 15CKT0201E, $0.3 \mathrm{~kW}$, Matsudo, Japan), an impingement tank including injection plates, a holding tube $(10 \mathrm{~mm}$ diameter with length of $4.99 \mathrm{~m}$ ), a vacuum tank (20 L), a liquid ring vacuum pump (Sunny-King SWP-172, $0.5 \mathrm{~kW}$, Taichung, Taiwan), a steam storage tank (14 L) and steam equipment. The instruments used for monitoring pressure and temperature in the system were pressure gauges, temperature gauges and PT100 temperature sensors. The pressure gauges of the sterilizer were located at the product pump (P1), vacuum tank (P2) and steam pressure (P3) system. The temperatures sensors were monitored for product at the infeed (T1), at sterilization (T2), after the holding tube (T3), after the vacuum cooler (T4) and at the infeed steam (T5).

All components in contact with the process liquids were made of stainless steel with heat resistant seals. The skid had an electrical cabinet for pump control and temperature display. The approximate dimensions of the prototype skid were length $=1.2 \mathrm{~m}$, width $=0.6 \mathrm{~m}$ and height $=1.5 \mathrm{~m}$ (Figure 1$)$.

The impingement tank (Figure 2) was made from stainless steel and was fitted with two pipes on opposite sides which were used for the inlet of product, and steam for direct collision, respectively. Both fluids flowed through the injection plate attached to the flow channel outlet. The injection plates were designed as a multiple impingement jet with an orifice to increase the heat transfer rate $[10,14]$. The injection plates were changeable to allow the investigation of different numbers of nozzles, which have an inverse relationship to the jet velocity and Reynolds number. The product injection plates were formed with two, three or four circular holes with a diameter of $2 \mathrm{~mm}$, as shown in Figure 3a. The steam injection plates were formed with six, nine or twenty circular holes with a diameter of $1 \mathrm{~mm}$, as shown in Figure 3b. The pitch between nozzles (defined as the pitch distance to nozzle diameter or $t / d$ ) was set at 5.5. Geers [7] and Specht [10] reported that the optimum value of $t / d$ was 5-6 to provide the highest average heat transfer. The distance between the product and the steam injection plates $(\mathrm{H})$ could be adjusted in the range 1-12 $\mathrm{mm}$ using a threaded socket. 


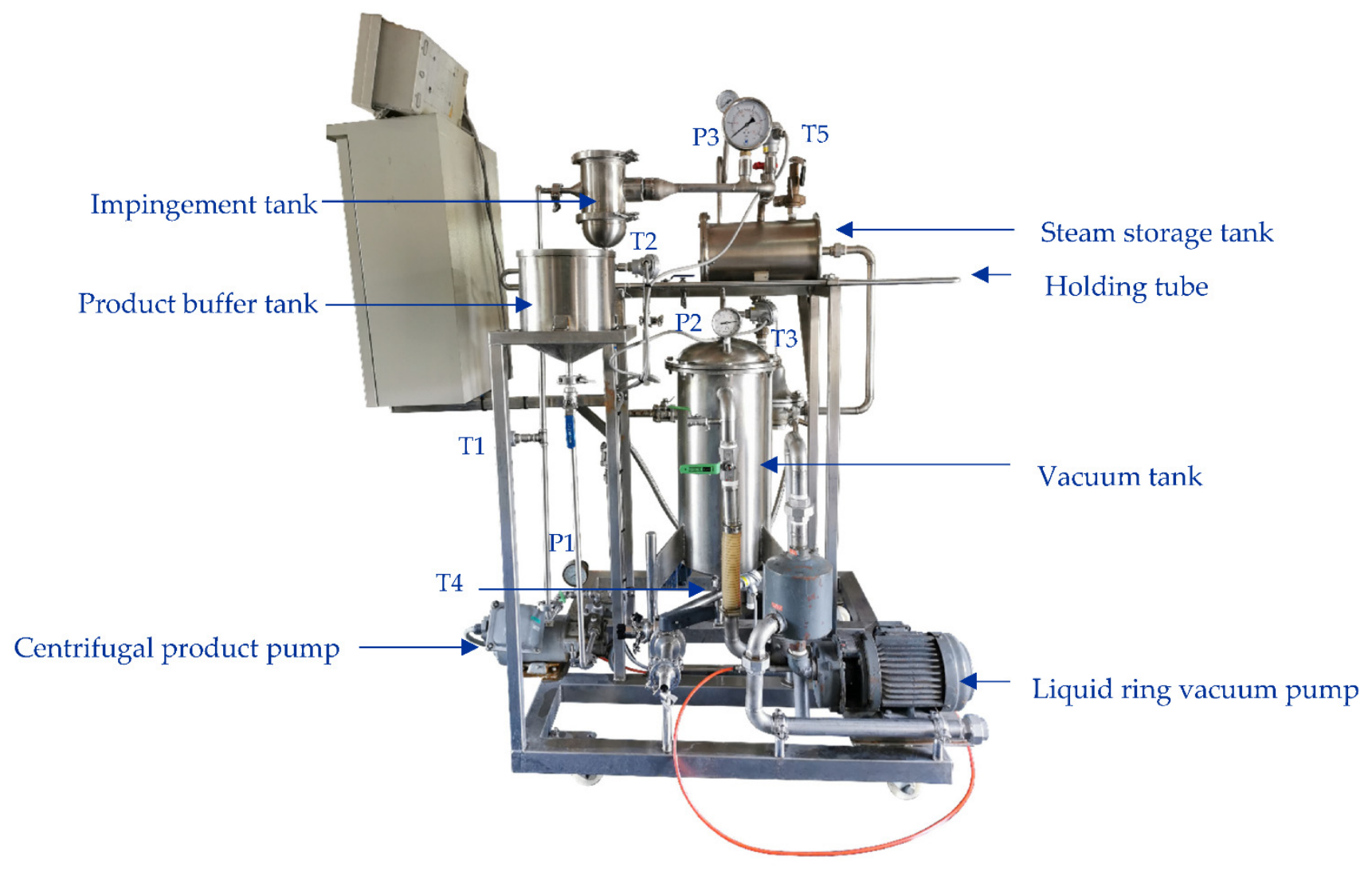

Figure 1. Prototype of impingement steam jet sterilizer.

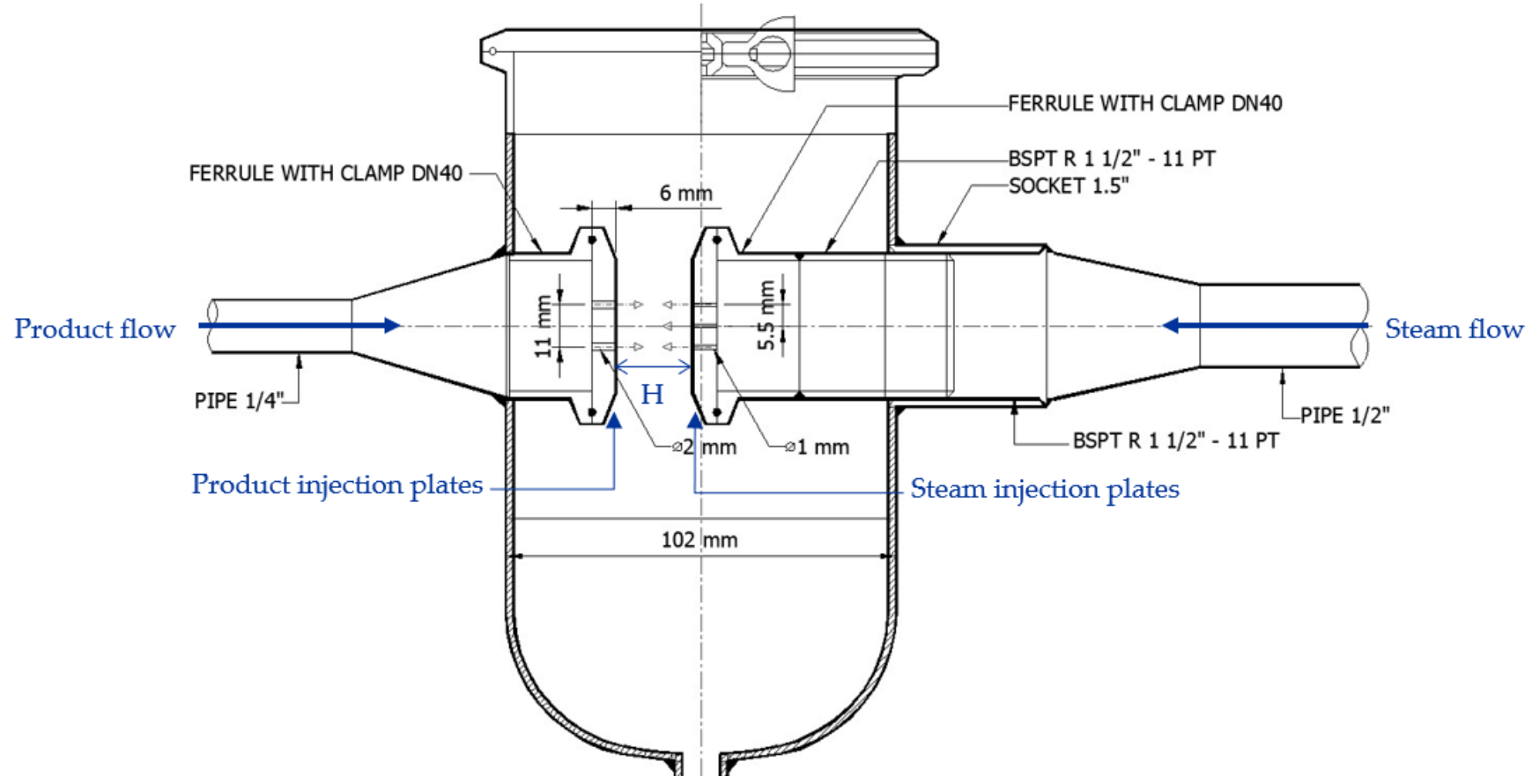

Figure 2. Impingement tank. 

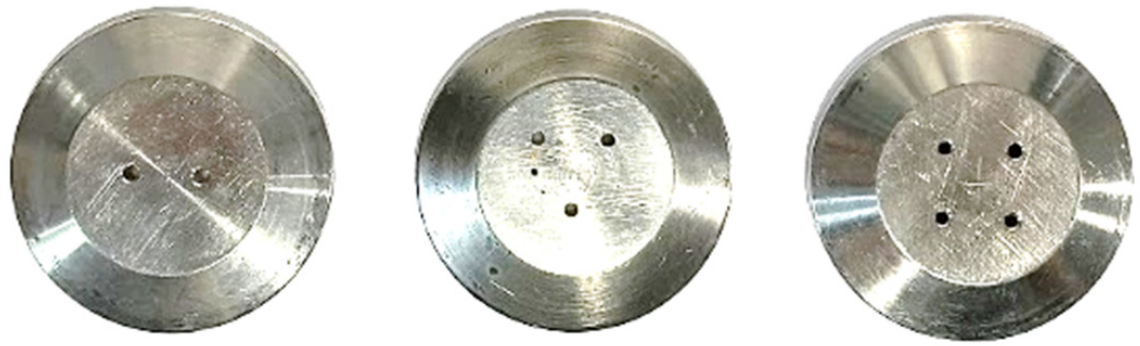

(a)
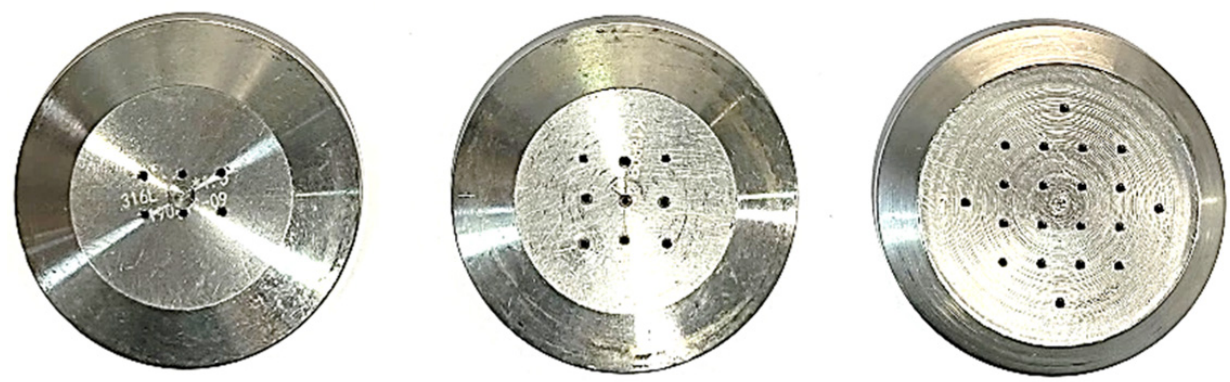

(b)

Figure 3. Product injection plates (a) Product injection plates; diameter $=2 \mathrm{~mm}$, number of nozzles $=2,3$ or 4 , and steam injection plates (b) Steam injection plates; diameter $=1 \mathrm{~mm}$, number of nozzles $=6,9$ or 20 .

The process can be described as follows. A centrifugal pump is used to pump the product from the buffer tank to the impingement tank to be impinged directly with the pressurized steam. The product is rapidly heated to the sterilization temperature by impinging and mixing it with steam. The product with condensate passes through the holding tube for the required amount of time. The product is cooled instantly using flash cooling by passing the liquid through a vacuum chamber (average vacuum pressure of $-690 \mathrm{mmHg}$ ). The cooling mechanism for such systems must be rapid and must remove any excess water resulting from the condensation in the direct heating method $[1,5]$.

\subsection{Water Test}

In this experiment, water was used as a product and was supplied to the impingement tank using the centrifugal pump with a regulated flow rate of $50 \mathrm{~kg} / \mathrm{h}$ (value was adjusted manually). The inlet water temperature was controlled at $60^{\circ} \mathrm{C}$ before mixing with steam by using a heating device in the water buffer tank. In a typical equipment configuration for continuous sterilization, the product inlet was pre-heated with hot-sterilized product in the heat exchanger to reduce steam consumption [1]. The heat regeneration was considered at $50 \%$, product was preheated from $20^{\circ} \mathrm{C}$ to $60{ }^{\circ} \mathrm{C}$ and then from $60{ }^{\circ} \mathrm{C}$ to $100{ }^{\circ} \mathrm{C}$ by the impingement steam jet [3]. The impingement conditions investigated were water injection plates with three different numbers of jet nozzle (two, three and four) and steam injection plates with three different numbers of jet nozzle (six, nine and twenty) and steam temperatures of 120,125 and $130{ }^{\circ} \mathrm{C}$, adjusted using a valve before the steam entered the impingement tank. The steam flow rate for all conditions was measured prior to testing, and the Reynolds number as described by Equation (1) was calculated and is shown in Table 1. The dimensionless jet-to-target distance, and an $\mathrm{H} / \mathrm{d}$ value of 5 (where $\mathrm{H}$ is the jet-to-target distance and $\mathrm{d}$ is the diameter of the steam nozzle that was set at $1 \mathrm{~mm}$ ) were fixed as constants to identify the best conditions, which were subsequently used to study $\mathrm{H} / \mathrm{d}$ with values of 1,3 or 7 . 
where $d$ is the inside diameter of the nozzle hole, $v$ is the average velocity of the fluid, $\rho$ is the density of the fluid and $\mu$ is its dynamic viscosity. The Reynolds number was used to represent the parameters of nozzle design and thermal fluid properties [5].

Table 1. Reynolds number of water and steam flow through nozzles.

\begin{tabular}{|c|c|c|c|c|c|}
\hline $\begin{array}{c}\text { Injection } \\
\text { Plates }\end{array}$ & $\begin{array}{l}\text { Water/Steam } \\
\text { Temperature }\end{array}$ & $\begin{array}{c}\text { Jet Nozzle } \\
\text { Diameter }\end{array}$ & $\begin{array}{c}\text { Jet Nozzle } \\
\text { Number }\end{array}$ & $\begin{array}{c}\text { Flow Rate } \\
\text { (kg/h) }\end{array}$ & $\begin{array}{c}\text { Reynolds } \\
\text { Number }\end{array}$ \\
\hline \multirow{3}{*}{ Water } & \multirow{3}{*}{$60^{\circ} \mathrm{C}$} & \multirow{3}{*}{$2 \mathrm{~mm}$} & 2 & 50.00 & 9476 \\
\hline & & & 3 & 50.00 & 6317 \\
\hline & & & 4 & 50.00 & 4738 \\
\hline \multirow{3}{*}{ Steam } & \multirow{3}{*}{$120^{\circ} \mathrm{C}$} & \multirow{3}{*}{$1 \mathrm{~mm}$} & 6 & 10.23 & 46,543 \\
\hline & & & 9 & 11.29 & 34,228 \\
\hline & & & 20 & 13.27 & 18,098 \\
\hline \multirow{3}{*}{ Steam } & \multirow{3}{*}{$125^{\circ} \mathrm{C}$} & \multirow{3}{*}{$1 \mathrm{~mm}$} & 6 & 12.42 & 55,721 \\
\hline & & & 9 & 14.41 & 43,123 \\
\hline & & & 20 & 15.55 & 20,932 \\
\hline \multirow{3}{*}{ Steam } & \multirow{3}{*}{$130^{\circ} \mathrm{C}$} & \multirow{3}{*}{$1 \mathrm{~mm}$} & 6 & 16.22 & 71,865 \\
\hline & & & 9 & 17.94 & 52,984 \\
\hline & & & 20 & 19.57 & 26,009 \\
\hline
\end{tabular}

The initial water temperature, steam temperature and sterilization temperature were monitored using temperature sensors (PT100). The results are presented in terms of the sterilization temperature, with the percentage of heat transfer efficiency calculated using Equation (2):

$$
\begin{aligned}
& \% \text { Efficiency }=\text { Thermal energy output/Thermal energy input } \\
& \text { Thermal energy input: } Q_{i n}=M_{S}\left(H_{v}(\% x)-H_{\mathcal{C}}(1-\% x)\right)
\end{aligned}
$$

where, $Q_{i n}, M_{s}, H_{v}, H_{c}$ and $\% x$ are steam energy input $(\mathrm{kJ} / \mathrm{h})$, steam flow rate $(\mathrm{kg} / \mathrm{h})$, enthalpy of vapor $(\mathrm{kJ} / \mathrm{kg})$, enthalpy of liquid $(\mathrm{kJ} / \mathrm{kg})$ and steam quality, respectively [24].

$$
\text { Thermal energy output: } Q_{\text {out }}=m_{2} C_{p 2} T_{2}-m_{1} C_{p 1} T_{1}
$$

where, $Q_{\text {out }}, m_{1}, m_{2}, C_{p 1}, C_{p 2}, T_{1}$ and $T_{2}$ are the thermal energy output $(\mathrm{kJ} / \mathrm{h})$, initial water flow rate $(\mathrm{kg} / \mathrm{h})$, final water flow rate $(\mathrm{kg} / \mathrm{h})$ (water + condensate), specific heat of initial water and final water $\left(\mathrm{kJ} / \mathrm{kg} /{ }^{\circ} \mathrm{C}\right)$, initial water temperature $\left({ }^{\circ} \mathrm{C}\right)$ and final water temperature $\left({ }^{\circ} \mathrm{C}\right)$, respectively [24].

\subsection{Pineapple Juice Test}

The suitable conditions from 2.2 were tested using pineapple juice. Frozen concentrated pineapple juice at $52^{\circ}$ Brix supplied by a Thai pineapple juice producer was reconstituted to $12^{\circ}$ Brix, with reverse osmosis drinking water. Pineapple juice samples before and after sterilization were analyzed for physicochemical properties and microbiological quality. Due to concentrated pineapple juice containing relatively low numbers of microorganisms, the diluted pineapple juice was kept for $8 \mathrm{~h}$ to obtain an initial level of microorganisms close to that of fresh pineapple juice. Berhanu, et al. [25] found that the aerobic mesophilic count in fresh pineapple juice from supermarkets and cafes was $5.2 \times 10^{4} \mathrm{CFU} / \mathrm{mL}$, and Hounhouigan et al. [26] found the range of bacterial counts of unpasteurized pineapple juice was $1 \times 10^{5}$ to $15 \times 10^{5} \mathrm{CFU} / \mathrm{mL}$.

Physicochemical properties and microbiological quality were analyzed. Pineapple juice color was measured using a colorimeter (MiniScan EZ 4500L Spectrophotometer Hunter Lab, Reston, VA, USA) using the Hunter scale $\left(\mathrm{L}^{*}, \mathrm{a}^{*}\right.$ and $\left.\mathrm{b}^{*}\right)$. Pineapple juice total soluble solids (TSS), expressed as ${ }^{\circ}$ Brix, were determined using a hand refractometer (Atago, Tokyo, Japan). Pineapple juice $\mathrm{pH}$ was measured using a $\mathrm{pH}$ meter (Apera Instruments 
PH700 Benchtop, Columbus, OH, USA). Microbiological analysis based on total plate counts of samples was carried out according to ISO methods (ISO 4833-1:2013).

Samples of at least $6 \mathrm{~L}$ of pineapple juice diluted and left for $8 \mathrm{hrs}$ were used in each batch. Untreated juice samples (each $100 \mathrm{~mL}$ ) at ambient temperature $\left(28-32{ }^{\circ} \mathrm{C}\right.$ ) were collected for the physicochemical and microbiological analyses. They were stored at $4{ }^{\circ} \mathrm{C}$ (control). Pineapple juice before passing into the sterilizer was controlled at $60^{\circ} \mathrm{C}$ using a heating device. The samples were collected using the same procedure as for the untreated juice for physicochemical and microbiological analyses. The pineapple juice was sterilized using the impingement steam jet technique. Moore, et al. [27] studied a process for sterilizing concentrated juice and fluid foods at $88-93{ }^{\circ} \mathrm{C}$ with a holding time of $19-24 \mathrm{~s}$.

Microbiological analysis was conducted at the end of the holding tube (designed residential time $=23.43 \mathrm{~s}$ ). After sterilization, the juice was cooled, and excess water was removed using a vacuum cooler. At the completion of each test for each batch, sterilized and cooled juice were collected from the vacuum cooler. For high temperature samples, after the bottles had been filled and sealed with screw caps, they were cooled in a water bath $\left(5^{\circ} \mathrm{C}\right)$, labeled and then stored under refrigeration $\left(4^{\circ} \mathrm{C}\right)$ until further analysis [28]. Microbiological quality was not considered after vacuum cooling because the vacuum system operated in batch mode and, consequently, the temperature at the beginning and end of the test was not constant. Especially at the beginning, the inlet steam temperature did not reach the specified temperature at which the product could be sterilized. The residual microorganisms at the beginning were gathered in the vacuum tank.

\subsection{Statistical Analysis}

Results are expressed as mean values \pm the standard deviation of three determinations. Data were analyzed using a one-way analysis of variance using the Statistical Package for Social Science (SPSS) version 26.0 software 2019 to test the level of significance at $5 \%$ probability $(p \leq 0.05)$. Duncan's new multiple range test was used to separate the means where significant differences existed.

\section{Results and Discussion}

\subsection{Effect of Jet Nozzle Number and Steam Temperatures of $120^{\circ} \mathrm{C}, 125^{\circ} \mathrm{C}$ or $130^{\circ} \mathrm{C}$}

Experiments were conducted to study the influence of the jet Reynolds number and steam temperature on the sterilization temperature and efficiency of heat transfer at $\mathrm{H} / \mathrm{d}=5$. The Reynolds number represented the nozzle design based on the product injection plates formed with two, three or four nozzles (diameter $2 \mathrm{~mm}$ ) and steam injection plates formed with six, nine or twenty nozzles (diameter $1 \mathrm{~mm}$ ). Furthermore, the effect was investigated of the steam temperature $\left(120,125\right.$ or $\left.130^{\circ} \mathrm{C}\right)$ on the steam jet Reynolds number; the results are shown in Table 2. The relationship of the sterilization temperature and heat transfer efficiency for various impingement conditions is shown in Figure 4 . The sterilization temperature tended to increase as the steam jet nozzle increased (six, nine or twenty) for all water jet nozzle numbers (two, three and four), which was directly proportional to the steam flow rate. The increase in the number of jets would be expected to increase the average heat transfer as more of the surface is exposed to the high transport region in the stagnation zone [29]. Except for the conditions with a steam temperature of $120^{\circ} \mathrm{C}$, with two water nozzles and six steam nozzles, the sterilization temperature was higher than with nine steam nozzles because the Reynolds numbers of the water and steam were the highest due to the increased turbulence intensity, and the jet Reynolds number having a large effect on the heat and mass transfer rates [13]. 
Table 2. Sterilization temperature and \% heat transfer efficiency of various impingement conditions for numbers of jets of water and steam and steam temperature $(t / d=5.5, H / d=5)$.

\begin{tabular}{|c|c|c|c|c|c|c|c|}
\hline \multicolumn{2}{|c|}{ Impingement Condition } & \multicolumn{2}{|c|}{ Steam Temperature $=120^{\circ} \mathrm{C}$} & \multicolumn{2}{|c|}{ Steam Temperature $=125^{\circ} \mathrm{C}$} & \multicolumn{2}{|c|}{ Steam Temperature $=130^{\circ} \mathrm{C}$} \\
\hline $\begin{array}{l}\text { Product } \\
\text { Nozzle }\end{array}$ & $\begin{array}{l}\text { Steam } \\
\text { Nozzle }\end{array}$ & $\begin{array}{c}\text { Sterilized } \\
\text { Temperature } \\
\left({ }^{\circ} \mathrm{C}\right)\end{array}$ & $\begin{array}{c}\text { \% Heat } \\
\text { Transfer } \\
\text { Efficiency }\end{array}$ & $\begin{array}{c}\text { Sterilized } \\
\text { Temperature } \\
\left({ }^{\circ} \mathrm{C}\right)\end{array}$ & $\begin{array}{c}\text { \% Heat } \\
\text { Transfer } \\
\text { Efficiency }\end{array}$ & $\begin{array}{c}\text { Sterilized } \\
\text { Temperature } \\
\left({ }^{\circ} \mathrm{C}\right)\end{array}$ & $\begin{array}{c}\text { \% Heat } \\
\text { Transfer } \\
\text { Efficiency }\end{array}$ \\
\hline 2 & 6 & $111.82 \pm 0.10^{\mathrm{e}}$ & $76.08 \pm 0.15^{\mathrm{e}}$ & $116.52 \pm 0.12^{d}$ & $71.29 \pm 0.34^{\mathrm{d}}$ & $121.29 \pm 0.25^{\mathrm{d}}$ & $64.01 \pm 1.04^{\mathrm{d}}$ \\
\hline 2 & 9 & $110.76 \pm 0.18^{c}$ & $71.99 \pm 0.28^{c}$ & $116.87 \pm 0.14^{\mathrm{e}}$ & $65.13 \pm 0.10^{b}$ & $122.79 \pm 0.12^{\mathrm{e}}$ & $60.90 \pm 1.44^{c}$ \\
\hline 2 & 20 & $112.16 \pm 0.13^{f}$ & $64.30 \pm 0.34^{\mathrm{a}}$ & $118.68 \pm 0.50^{f}$ & $64.12 \pm 1.15^{\mathrm{ab}}$ & $124.13 \pm 0.07^{\mathrm{fg}}$ & $58.87 \pm 0.44^{\mathrm{a}}$ \\
\hline 3 & 6 & $107.91 \pm 0.29^{a}$ & $72.76 \pm 0.24^{c}$ & $113.57 \pm 0.15^{\mathrm{a}}$ & $68.95 \pm 0.17^{c}$ & $119.63 \pm 0.04^{\mathrm{a}}$ & $62.83 \pm 0.32^{\mathrm{d}}$ \\
\hline 3 & 9 & $110.57 \pm 0.15^{c}$ & $72.24 \pm 0.28^{c}$ & $116.15 \pm 0.11^{\mathrm{c}}$ & $65.17 \pm 0.66^{b}$ & $120.75 \pm 0.07^{c}$ & $59.92 \pm 0.03^{a b c}$ \\
\hline 3 & 20 & $112.20 \pm 0.15^{\mathrm{f}}$ & $64.93 \pm 0.95^{\mathrm{a}}$ & $119.17 \pm 0.17^{g}$ & $63.65 \pm 0.47^{a}$ & $124.28 \pm 0.02^{h}$ & $59.12 \pm 0.48^{a b}$ \\
\hline 4 & 6 & $110.19 \pm 0.17^{b}$ & $74.52 \pm 0.51^{\mathrm{d}}$ & $115.53 \pm 0.09^{b}$ & $71.57 \pm 0.11^{\mathrm{d}}$ & $120.41 \pm 0.07^{b}$ & $62.72 \pm 0.39 \mathrm{~d}$ \\
\hline 4 & 9 & $111.17 \pm 0.04^{\mathrm{d}}$ & $70.27 \pm 0.15^{b}$ & $116.24 \pm 0.05^{c}$ & $64.33 \pm 0.56^{\mathrm{ab}}$ & $121.41 \pm 0.07^{\mathrm{d}}$ & $60.41 \pm 0.35^{b c}$ \\
\hline 4 & 20 & $112.82 \pm 0.18^{g}$ & $64.81 \pm 0.54^{\mathrm{a}}$ & $118.80 \pm 0.17^{\mathrm{f}}$ & $63.69 \pm 0.76^{\mathrm{a}}$ & $124.05 \pm 0.11^{\mathrm{f}}$ & $59.28 \pm 0.89^{a b}$ \\
\hline
\end{tabular}

Values are mean \pm standard deviation, $n=3{ }^{\mathrm{a}-\mathrm{h}}=$ superscript lowercase letters in columns indicate a significant $(p \leq 0.05)$ difference at each the impingement conditions using Duncan's new multiple rang test.

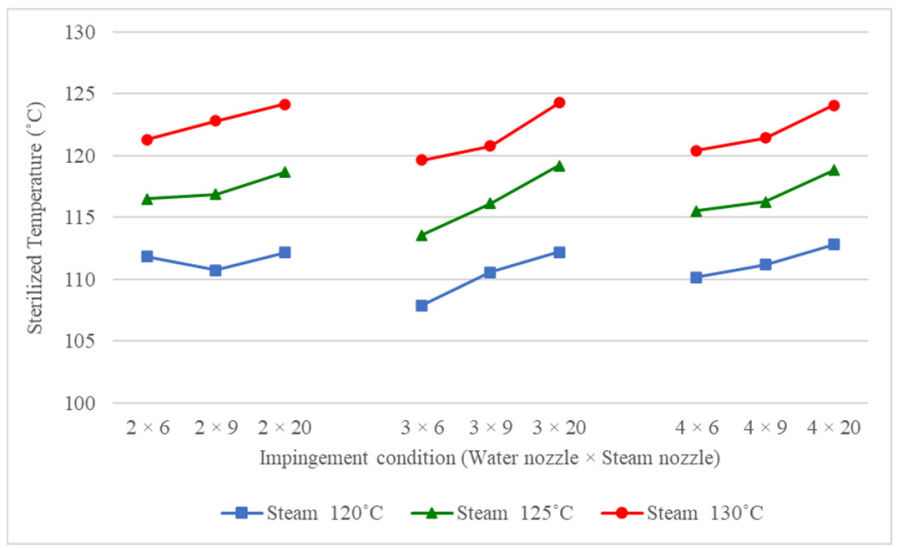

(a)

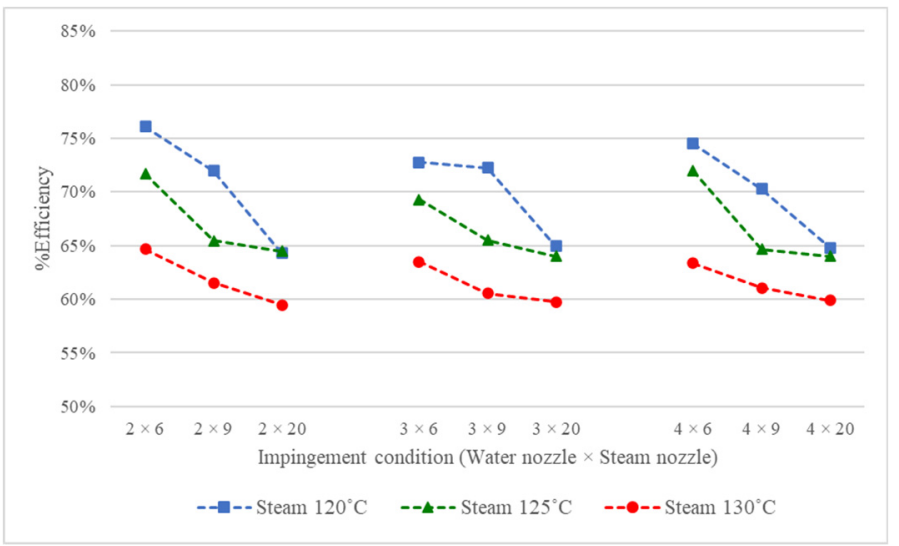

(b)

Figure 4. Relationship between sterilization temperature (a) and heat transfer efficiency (b) for various impingement conditions of numbers of water and steam jets and steam temperature $(t / d=5.5$, $\mathrm{H} / \mathrm{d}=5)$.

In contrast, the thermal efficiency tended to decrease as the jet nozzle number for steam increased (six, nine and twenty) for all the water jet nozzle numbers due to the increasing number of steam jets increasing the steam flow rate. The steam energy input increased with increasing sterilization temperature because a high heat transfer efficiency is associated with turbulence intensity or a high Reynolds number. At the same steam flow rate, a lower number of steam nozzles increased the fluid velocity and Reynolds number. The high Reynolds number caused more efficient turbulence and product mixing [15,30]. According to the results of Ekkad et al. [17], the Nusselt numbers increased significantly as Reynolds number increased $(5000,10,000,15,000)$ for all configurations $(\mathrm{H} / \mathrm{d}=1$ to 5 and $\mathrm{t} / \mathrm{d}=4$ to 8 ).

From the experiment, the efficiency of the impingement steam jet application was in the range $59.12-76.08 \%$. The steam energy input calculation was based on steam quality [23] at $74 \%$, which was low compared to other types of direct heating due to heat energy loss to the surroundings because the impingement tank was not insulated.

A water and steam jet nozzle layout of $2 \times 6$ nozzles had a high heat transfer efficiency at all tested steam temperatures, with the steam temperature at $120{ }^{\circ} \mathrm{C}$ providing the highest heat transfer efficiency $(76.08 \%)$. Therefore, these conditions were used to study the dimensionless jet-to-target distance $(\mathrm{H} / \mathrm{d})$ and its effect on heat transfer efficiency. 


\subsection{Effect of Dimensionless Jet-to-Target Distance}

The conditions studied were water and steam jet nozzle numbers of $2 \times 6$ at a steam temperature of $120^{\circ} \mathrm{C}$, with various $\mathrm{H} / \mathrm{d}$ values $(1,3,5,7)$; the results are shown in Table 3 . $\mathrm{H} / \mathrm{d}=1$ had the significantly highest sterilization temperature $\left(115.97^{\circ} \mathrm{C}\right)$ and heat transfer efficiency $(78.45 \%)$ compared to other conditions. There was no significant difference between $\mathrm{H} / \mathrm{d}=3$ and $\mathrm{H} / \mathrm{d}=5$, and both were greater than $\mathrm{H} / \mathrm{d}=7$.

Table 3. Sterilization temperature and \% heat transfer efficiency of jet nozzle numbers for water and steam at $2 \times 6$ and steam temperature of $120^{\circ} \mathrm{C}$ for varying $\mathrm{H} / \mathrm{d}$ values $(\mathrm{t} / \mathrm{d}=5.5)$.

\begin{tabular}{|c|c|c|c|c|}
\hline \multicolumn{3}{|c|}{ Impingement Condition } & \multicolumn{2}{|c|}{ Steam Temperature $=120^{\circ} \mathrm{C}$} \\
\hline Product Nozzles & Steam Nozzles & H/d & Sterilization Temperature $\left({ }^{\circ} \mathrm{C}\right)$ & $\%$ Heat Transfer Efficiency \\
\hline \multirow{4}{*}{2} & \multirow{4}{*}{6} & 1 & $115.97 \pm 0.37^{c}$ & $78.45 \pm 0.21^{c}$ \\
\hline & & 3 & $111.93 \pm 0.13^{b}$ & $75.63 \pm 0.82^{b}$ \\
\hline & & 5 & $111.82 \pm 0.10^{b}$ & $76.08 \pm 0.20^{b}$ \\
\hline & & 7 & $109.11 \pm 0.22^{\mathrm{a}}$ & $73.72 \pm 0.64$ \\
\hline
\end{tabular}

Values are mean \pm standard deviation, $n=3 .^{\mathrm{a}-\mathrm{c}}=$ superscript lowercase letters in columns indicate a significant $(p \leq 0.05)$ difference at each the impingement conditions using Duncan's new multiple rang test.

Figure $5 a, b$ indicate that the sterilization temperature and the heat transfer efficiency decreased with an increase in the jet-to-target distance. For a low value of $\mathrm{H} / \mathrm{d}$, both the velocity and turbulence increased greatly, which increased the heat transfer rate, whereas for a high value of $\mathrm{H} / \mathrm{d}$, the heat transfer rate decreased due to adjacent jet interactions occurring before impingement [6]. Specht [10] and Yamane et al. [21] studied the influence of $\mathrm{t} / \mathrm{d}$ (4 to 8 ) and $\mathrm{H} / \mathrm{d}$ (2 to 10) on the averaged Nusselt numbers; the averaged Nusselt numbers were approximately constant up to $\mathrm{H} / \mathrm{d}$ of about 5 , and then decreased continuously. With the exception of Yamane's experiment, where $t / d=4$, the averaged Nusselt numbers significant increased at $\mathrm{H} / \mathrm{d}=2$.

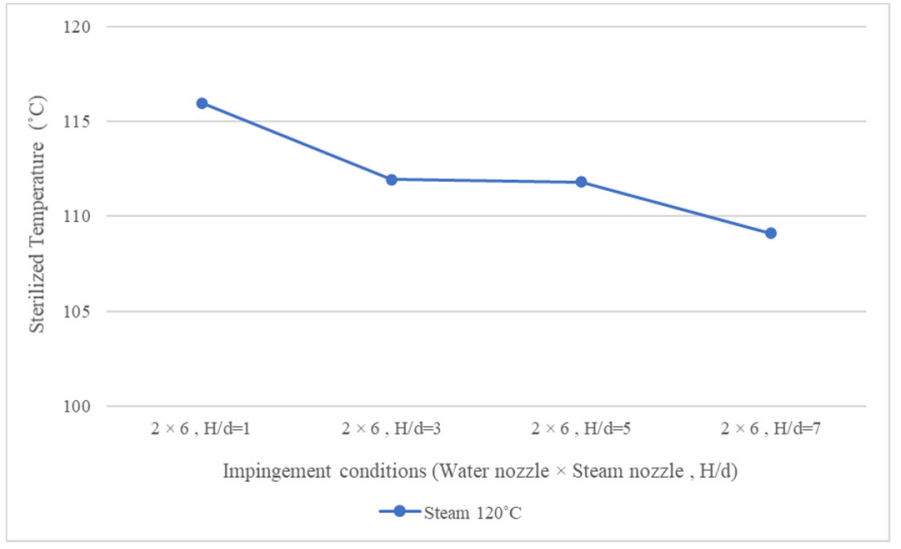

(a)

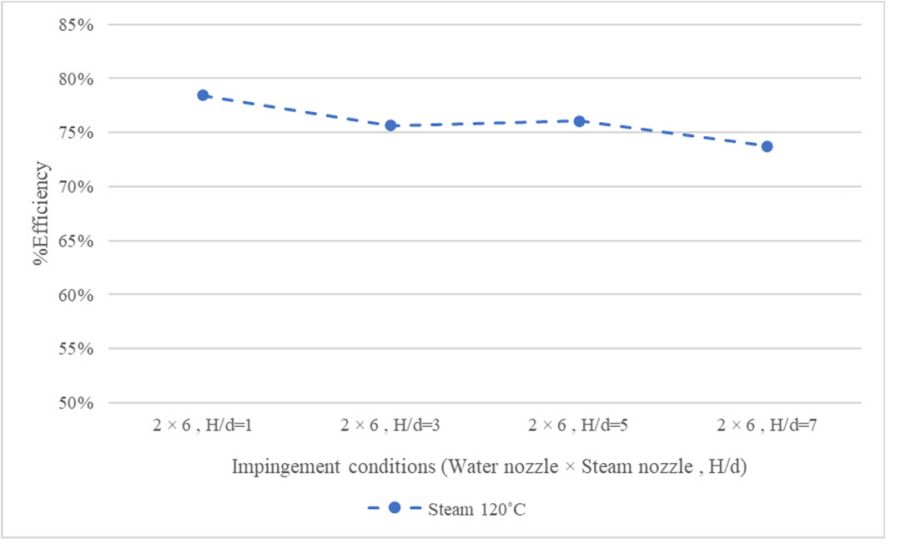

(b)

Figure 5. Relationship of sterilization temperature with: (a) \% heat transfer efficiency (b) jet nozzle numbers of water and steam at $2 \times 6$ and steam temperature at $120{ }^{\circ} \mathrm{C}$ and various $\mathrm{H} / \mathrm{d}$ values $(t / d=5.5)$.

\subsection{Pineapple Juice Test}

The highest heat transfer efficiency conditions were for jet nozzle number of pineapple juice and steam $=2 \times 6, \mathrm{H} / \mathrm{d}=1$ and $\mathrm{t} / \mathrm{d}=5.5$ at an average steam temperature of $121.66^{\circ} \mathrm{C}$ (average steam flow rate $10.96 \mathrm{~kg} / \mathrm{h}$ ) and a pineapple juice flow rate of $53.76 \mathrm{~kg} / \mathrm{h}$. The average temperatures of the pineapple juice infeed (T1) at sterilization (T2), after the holding tube (T3) and after the vacuum cooler (T4) were $60.21{ }^{\circ} \mathrm{C}, 117.18{ }^{\circ} \mathrm{C}, 92.70{ }^{\circ} \mathrm{C}$ and $64.63{ }^{\circ} \mathrm{C}$, respectively, as shown in Figure 6. The average heat transfer efficiency was $77.87 \%$. 


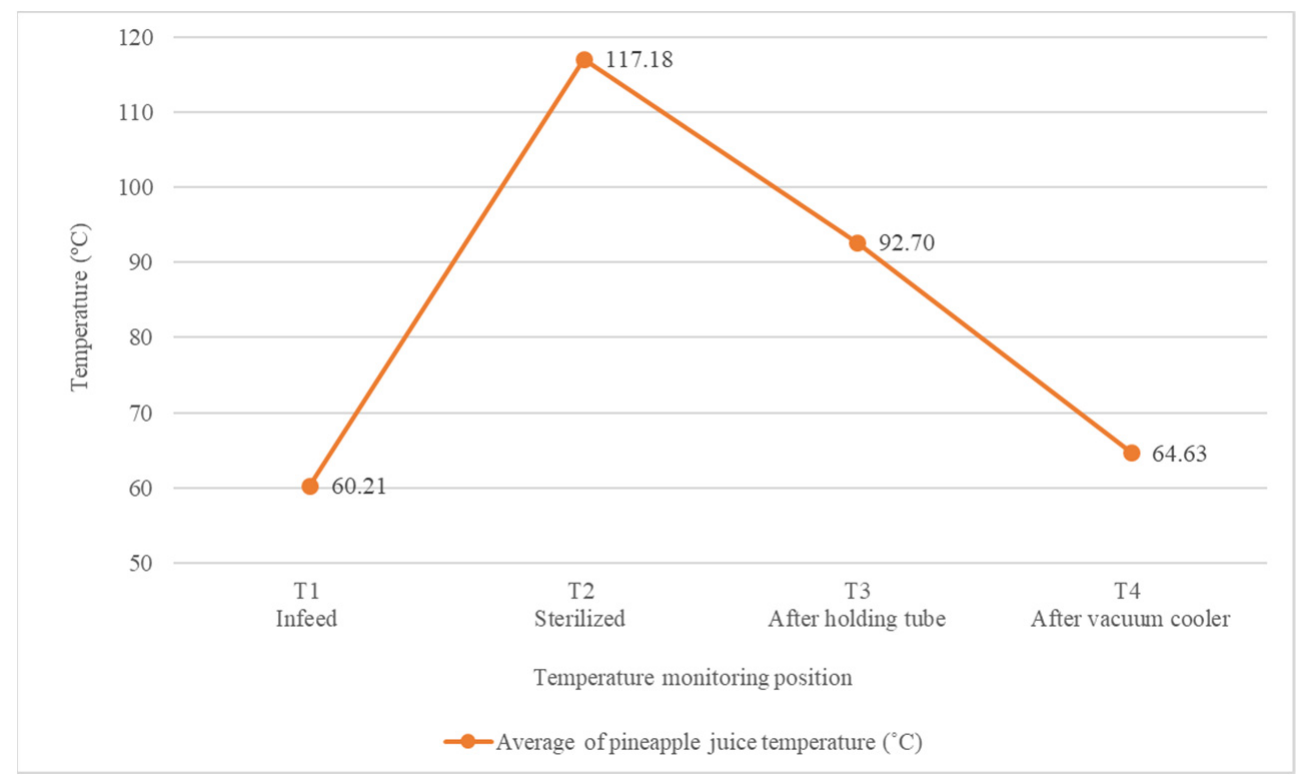

Figure 6. Product temperatures in impingement steam jet sterilizer with jet nozzle numbers of product and steam at $2 \times 6$, steam temperature at $120^{\circ} \mathrm{C}$ and $\mathrm{H} / \mathrm{d}=1(\mathrm{t} / \mathrm{d}=5.5)$.

The pineapple juice was sterilized at $117.18^{\circ} \mathrm{C}$ and then the temperature decreased to $92.70^{\circ} \mathrm{C}$ with an average residential time of $22.73 \mathrm{~s}$. Microbiological analysis indicated that the total plate count of the untreated pineapple juice of $1.8 \times 10^{4}-3.0 \times 10^{5} \mathrm{CFU} / \mathrm{mL}$ decreased to $42-340 \mathrm{CFU} / \mathrm{mL}$ during the temperature controlling operation at $60{ }^{\circ} \mathrm{C}$. They were reduced to less than $1.0 \mathrm{CFU} / \mathrm{mL}$ after sterilization by impingement steam jet (Table 4), in accordance with the standard for sterilized beverages in a sealed container [31].

Table 4. Color, $\mathrm{pH}$, TSS and total plate count of pineapple juice.

\begin{tabular}{|c|c|c|c|c|c|c|}
\hline \multirow{2}{*}{$\begin{array}{l}\text { Diluted Pineapple } \\
\text { Juice Treatment }\end{array}$} & \multicolumn{3}{|c|}{ Color } & \multirow{2}{*}{$\mathrm{pH}$} & \multirow{2}{*}{$\begin{array}{c}\text { TSS } \\
\left({ }^{\circ} \text { Brix }\right)\end{array}$} & \multirow{2}{*}{$\begin{array}{l}\text { Total Plate Count } \\
\text { (CFU/mL) }\end{array}$} \\
\hline & $L^{*}$ & $a^{*}$ & $\mathbf{b}^{*}$ & & & \\
\hline $\begin{array}{l}\text { Untreated at ambient } \\
\text { temperature }\end{array}$ & $33.15 \pm 0.57^{a}$ & $-0.50 \pm 0.23^{a}$ & $14.30 \pm 0.82^{\mathrm{a}}$ & $4.48 \pm 0.47^{\mathrm{a}}$ & $12.0 \pm 0.00^{b}$ & $1.8 \times 10^{4}-3.0 \times 10^{5}$ \\
\hline Pretreated at $60^{\circ} \mathrm{C}$ & $33.36 \pm 0.76^{a}$ & $-0.48 \pm 0.16^{\mathrm{a}}$ & $14.10 \pm 0.37^{\mathrm{a}}$ & $4.20 \pm 0.03^{a}$ & $12.0 \pm 0.00^{\mathrm{b}}$ & $42-340$ \\
\hline After passing holding tube & na & na & na & na & na & $<1.0$ \\
\hline $\begin{array}{l}\text { After passing vacuum } \\
\text { cooler }\end{array}$ & $32.24 \pm 0.28^{a}$ & $-0.27 \pm 0.30^{\mathrm{a}}$ & $14.58 \pm 0.35^{\mathrm{a}}$ & $4.20 \pm 0.02^{\mathrm{a}}$ & $11.87 \pm 0.07^{\mathrm{a}}$ & na \\
\hline
\end{tabular}

Values are mean \pm standard deviation, $n=3{ }^{a, b}=$ superscript lowercase letters in columns indicate a significant $(p \leq 0.05)$ difference at each the pineapple juice treatments using Duncan's new multiple rang test.

The physicochemical quality (Table 4) $\mathrm{pH}$ values were not significantly different between the untreated pineapple juice, juice pretreated at $60{ }^{\circ} \mathrm{C}$, and juice after passing through the vacuum cooler, and ranged from 4.20-4.48, which is in line with other studies $[27,32,33]$.

A similar result in the color, $\mathrm{L}^{*}$ (lightness) and $\mathrm{b}^{*}$ (yellow-blue) were not significantly different in untreated, pretreated, and sterilized pineapple juice due to the pineapple juice being cooled instantly using flash cooling, as well as the removal of any excess water that may have come from condensation [5]. The change in pineapple juice color is influenced by both nonenzymatic browning and pigment destruction, and the phenomena that occur during heating and storage of pineapple juice [34]. Hounhouigan et al. [32] reported the formation of Hydroxymethylfurfural (HMF) as nonenzymatic browning was initiated only at $95^{\circ} \mathrm{C}$ with a minimum time of $30 \mathrm{~min}$. 
The TSS of pineapple juice after passing the vacuum cooler $\left(11.87^{\circ}\right.$ Brix $)$ was lower than for the initial pineapple juice $\left(12.00^{\circ}\right.$ Brix). The efficiency of excess water removal by the vacuum cooler was $99.45 \%$. The balance between water addition as steam and water extraction as vapors from the vacuum cooler was determined by the temperature of the product leaving the vacuum cooler being some $1{ }^{\circ} \mathrm{C}$ to $2{ }^{\circ} \mathrm{C}$ higher than that of the product before mixing with steam [3]. From the experiment, the average different temperature between the pineapple juice after the vacuum cooler (T4) and infeed (T1) was $4.42{ }^{\circ} \mathrm{C}$. Lewis et al. [3] reviewed the experimental relationships between differential temperature and concentration/dilution in direct heating systems of milk products. The temperature difference was approximately $4-5{ }^{\circ} \mathrm{C}$ and the dilution in range $0.30-0.45 \%$ (excess water removal 99.55-99.70\%).

In liquid food sterilization, the sterilizing temperature and holding time are considered in the sterilizer design, while the Reynolds number and nozzle configuration are factors considered in the impingement steam jet design. Our results indicated the highest heat transfer efficiency was produced using jet nozzle numbers for product and steam of $2 \times 6$, $\mathrm{H} / \mathrm{d}=1$ and $\mathrm{t} / \mathrm{d}=5.5$ with a high Reynolds number. These parameters can be scaled up for commercial production depending on the product properties and flow rate. Moreover, the impingement stem jet method can be applied to high acid and low acid liquid food with low pulp.

\section{Conclusions}

This paper discussed the effect of the Reynolds Number and the dimensionless jet-totarget distance, $\mathrm{H} / \mathrm{d}$, on sterilization temperature and heat transfer efficiency. The Reynolds number was based on jet nozzle numbers and steam under turbulent flow.

At a constant $\mathrm{H} / \mathrm{d}=5$ and $\mathrm{t} / \mathrm{d}=5.5$, a higher sterilization temperature was associated with higher steam temperature and higher numbers of jet nozzles due to the greater steam flow rate. Conversely, higher heat transfer efficiency was associated with a higher Reynolds number or turbulence intensity. The impingement conditions producing the highest efficiency were with jet nozzle numbers and steam plate numbers of two and six, respectively, at a steam temperature of $120^{\circ} \mathrm{C}$. The Reynolds numbers of the water and steam jet nozzles were 9,476 and 46,543, respectively. For $\mathrm{H} / \mathrm{d}$ in the range 1-7, the design with $\mathrm{H} / \mathrm{d}=1$ had the highest sterilization temperature and thermal efficiency.

Pineapple juice was sterilized using the designed impingement steam jet technology with optimal conditions being jet nozzle numbers and steam plates of two and six, respectively, a steam temperature of $120^{\circ} \mathrm{C}, \mathrm{H} / \mathrm{d}=1$ and $\mathrm{t} / \mathrm{d}=5.5$. It was found that the total plate count decreased from $10^{4}-10^{5} \mathrm{CFU} / \mathrm{mL}$ to less than $1.0 \mathrm{CFU} / \mathrm{mL}$, which was consistent with the standard for sterilized beverages in a sealed container. Furthermore, the physicochemical qualities of color and $\mathrm{pH}$ were not significantly changed by the sterilization process. The efficiency of excess water removal by the vacuum cooler was $99.45 \%$.

Author Contributions: Conceptualization, W.S. and C.I.; methodology, W.S. and C.I.; software, W.S.; validation, W.S. and C.I.; formal analysis, W.S. and C.I.; investigation, W.S.; resources, W.S. and C.I.; data curation, W.S.; writing—original draft preparation, W.S.; writing—review and editing, C.I.; visualization, W.S.; supervision, C.I.; project administration, C.I.; funding acquisition, C.I. All authors have read and agreed to the published version of the manuscript.

Funding: This research received no external funding.

Institutional Review Board Statement: Not applicable.

Informed Consent Statement: Not applicable.

Data Availability Statement: This study did not report any data.

Acknowledgments: This research was funded by the Graduate School Fellowship Program in agriculture and agro-industry from the Agricultural Research Development Agency (Public Organi- 
zation) as of fiscal year 2020 and the Faculty of Engineering at Kamphaeng Saen Scholarship for Graduate Students.

Conflicts of Interest: The authors declare no conflict of interest.

\section{References}

1. Doran, P.M. Bioprocess Engineering Principles, 2nd ed.; Elsevier: Amsterdam, The Netherlands, 2013; pp. 761-852. ISBN 978-0-12220851-5.

2. Jelen, P. Experience with Direct and Indirect UHT Processing of Milk-A Canadian Viewpoint. J. Food Prot. 1982, 45, 878-883. [CrossRef] [PubMed]

3. Lewis, M.; Heppell, N. Continuous Thermal Processing of Foods Pasteurization and UHT Sterilization; Aspen Publishers, Inc.: Gaithersburg, MD, USA, 2000; pp. 57-103. ISBN 0-8342-1259-5.

4. Mota, F.A.S.; Carvalho, E.P.; Ravagnani, M.A.S.S. Modeling and Design of Plate Heat Exchanger. In Heat Transfer Studies and Applications; Kazi, S.N., Ed.; IntechOpen: London, UK, 2015; pp. 165-199. [CrossRef]

5. Emond, S. Continuous Heat Processing. In Thermal Technologies in Food Processing; Richardson, P., Ed.; Woodhead Publishing Limited: Cambridge, UK, 2001; pp. 29-48. ISBN 1-85573-558-X.

6. Xu, Q.; Liu, W.; Li, W.; Yao, T.; Chu, X.; Guo, L. Experimental investigation on interfacial behavior and its associated pressure oscillation in steam jet condensation in subcooled water flow. Int. J. Heat Mass Transf. 2019, 145, 118779. [CrossRef]

7. Geers, L.F.G. Multiple Impinging Jet Arrays: An Experimental Study on Flow and Heat Transfer. Ph.D. Thesis, Technical University Delft, Delft, The Netherlands, 9 February 2004.

8. Penumadu, P.S.; Rao, A.G. Numerical Investigations of Heat Transfer and Pressure Drop Characteristics in Multiple Jet Impingement System. Appl. Therm. Eng. 2016, 110, 1511-1524. [CrossRef]

9. Tsaoulidis, D.; Angeli, P. Liquid-liquid Dispersions in Intensified Impinging-jets Cells. Chem. Eng. Sci. 2017, 171, 149-159. [CrossRef]

10. Specht, E. Impinging Jet Drying. In Modern Drying Technology, 1st ed.; Tsotsas, E., Mujumdar, A.S., Eds.; Wiley-VCH GmbH: Weinheim, Germany, 2014; pp. 1-25. ISBN 978-3-527-31560-4.

11. Wen, X.; Li, Z.; Zhou, W.; Liu, Y. Interaction of Dual Sweeping Impinging Jets at Different Reynolds Numbers. Phys. Fluids 2018, 30, 105105. [CrossRef]

12. Lawal, D.U.; Abubakar, A.A.; Alharbi, M.B.; Ben-Mansour, R. A Numerical Study of Steady and Unsteady Flow and Heat Transfer from a Confined Slot Jet Impinging on a Constant Heat Flux Wall. J. Mech. Eng. Technol. 2014, 6, 1-17.

13. Zuckerman, N.; Lior, N. Jet Impingement Heat Transfer: Physics, Correlations, and Numerical Modeling. Adv. Heat Transf. 2006, $39,565-574$.

14. Shakouchi, T.; Kito, M.; Tsuda, M.; Tsujimoto, K.; Ando, T. Flow and Heat Transfer of Impinging Jet from Notched-Orifice Nozzle. J. Fluid Sci. Technol. 2011, 6, 453-464. [CrossRef]

15. Ostermann, R.A. Direct Steam Injection Heating of Liquid Food Products. Master's Thesis, Oklahoma State University, Stillwater, OK, USA, December 2005.

16. Patil, P.M.; Yadav, A.P.; Patil, P.A. Comparative Study between Heat Transfer through Laminar Flow and Turbulent Flow. Int. J. Innov. Res. Sci. Eng. Technol. 2015, 4, 2223-2226.

17. Ekkad, S.V.; Gao, L.; Hebert, R.T. Effect of Jet-to-Jet Spacing in Impingement Arrays on Heat Transfer. In Proceedings of the IMECE2002 ASME International Mechanical Engineering Congress \& Exposition, New Orleans, LA, USA, 17-22 November 2002.

18. Glynn, C.; O'Donovan, T.; Murray, D.B. Jet Impingement Cooling. In Proceedings of the 9th UK National Heat Transfer Conference, Manchester, UK, 5-6 September 2005.

19. Mistry, E.; Prajapati, J.P.; Suneeta, V.P. Innovative Steam Injection for Milk Processing. In Proceedings of the 11th Indian Dairy Industry-Opportunities and Challenges. SMC College of Dairy Science, Anand Agricultural University, Anand, GJ, India, 8-9 January 2015.

20. Xu, Q.; Liu, W.; Li, W.; Yao, T.; Chu, X.; Guo, L. Numerical investigation on thermal hydraulic characteristics of steam jet condensation in subcooled water flow in pipes. Int. J. Heat Mass Transf. 2022, 184, 122277. [CrossRef]

21. Yamane, Y.; Ichikawa, Y.; Yamamoto, M.; Honami, S. Effect of Injection Parameters on Jet Array Impingement Heat Transfer. Int. J. Gas Turbine Propuls. Power Syst. 2012, 4, 27-34. [CrossRef]

22. Lytle, D.; Webb, B.W. Air Jet Impingement Heat Transfer at Low Nozzle-Plate Spacings. Int. J. Heat Mass Transf. 1994, 37, 1687-1697. [CrossRef]

23. Petruzzi, L.; Campaniello, D.; Speranza, B.; Corbo, M.R.; Sinigaglia, M.; Bevilacqua, A. Thermal Treatments for Fruit and Vegetable Juices and Beverages: A Literature Overview. Compr. Rev. Food Sci. Food Saf. 2017, 16, 668-691. [CrossRef] [PubMed]

24. Singh, R.P.; Heldman, D.R. Introduction to Food Engineering, 2nd ed.; Academic Press, Inc.: Cambridge, MA, USA, 1993 ; pp. 95-112. ISBN 0-12-646381-6.

25. Berhanu, M.; Adal, M.; Sahile, S. Microbial Quality Spectrum of Packed and Fresh Fruit Juices in Gondar Town Supermarkets and Cafes, Northwestern Ethiopia. J. Microbiol. Res. 2020, 10, 45-54.

26. Hounhouigan, M.H.; Linnemann, A.R.; Soumanou, M.M.; Boeke, M.A.J.S.V. Effect of Processing on the Quality of Pineapple Juice. Food Rev. Int. 2014, 30, 112-133. [CrossRef] 
27. Moore, K.L.; Dake, T.W.; McBride, J.E. Juice Sterilization Process. EP0247245A1, 2 December 1987.

28. Leneveu, J.C.; Quentin, B.; Assemat, S.; Remize, F. Maintaining Physicochemical, Microbiological, and Sensory Quality of Pineapple Juice (Ananas comosus, Var. 'Queen Victoria') through Mild Heat Treatment. Processes 2020, 8, 1186. [CrossRef]

29. Molana, M.; Banooni, S. Investigation of Heat Transfer Processes Involved Liquid Impingement Jets: A Review. Braz. J. Chem. Eng. 2013, 30, 413-435. [CrossRef]

30. O'Donovan, T.S. Fluid Flow and Heat Transfer of an Impinging Air Jet. Ph.D. Thesis, University of Dublin, Dublin, Ireland, March 2005.

31. Notification of Ministry of Public Health (No. 356) 2013. Re: Beverages in Sealed Container. Available online: http:/ / food.fda. moph.go.th/law/data/announ_moph/V.English/P356_E.pdf (accessed on 7 December 2021).

32. Hounhouigan, M.H.; Linnemann, A.R.; Soumanou, M.M.; Van Boekel, M.A.J.S. Effect of Heat Treatment on Yeast Inactivation, Vitamin C and Physicochemical Quality of Fresh Pineapple Juice. Afr. J. Food Sci. 2020, 14, 256-264.

33. Lagnika, C.; Adjovi, Y.C.; Lagnika, L.; Gogohounga, F.O.; Do-Sacramento, O.; Koulony, R.K.; Sanni, A. Effect of Combining Ultrasound and Mild Heat Treatment on Physicochemical, Nutritional Quality and Microbiological Properties of Pineapple Juice. Food Sci. Nutr. 2017, 8, 227-241. [CrossRef]

34. Tobolková, B.; Durec, J.; Belajová, E.; Mihalíková, M.; Polovka, M.; Suhaj, M.; Daško, L.; Šimko, P. Effect of Light Conditions on Physico-Chemical Properties of Pineapple Juice with Addition of Small Pineapple Pieces During Storage. J. Food Nutr. Res. 2013, 52, 181-190. 